4. Morse N., O. Glazunova, «Models of effective use of information and communication and distance learning technologies in the higher educational institution «Information technologies and teaching aids, 2008, № 6 (2), [Electronic resource]. Access mode: scholar.google.com.ua/citations?user= BujWYRcAAAAJ\&hl=en

5. Onkovich GV Media didactics of higher school: Ukrainian experience / G.V. Onkovych // Higher education of Ukraine. 2013. № 1. P. 23-29.

6. Sakhnevych I.A Pedagogical conditions of application of media educational technologies in professional training of future oil and gas specialists: author's ref. dis. for science. degree. Cand. ped. Science: special. 13.00.04 «Theory and methods of professional education «/ IA Sakhnevych. Kyiv. 2012. 20 p.

7. Fedorov A.V. Dictionary of terms on media education, media pedagogy, media literacy, media competence. / AV Fedorov. M .: MOO «Information for All», 2014. 64 p.

DOI https://doi.org/10.30525/978-9934-588-80-8-2.57

\title{
ДОСВІД ВИКОРИСТАННЯ ЗАСОБІВ МАСОВОЇ КОМУНІКАЦЇ̈ У ВСТУПНІЙ КАМПАНІЇ ВІЙСЬКОВОГО ІНСТИТУТУ
}

\author{
Міхсев Ю. I. \\ кандидат технічних наук, \\ заступник начальника науково-дослідного відділу інформачійної \\ та кібернетичної безпеки наукового центру \\ Житомирський військовий інститут імені С. П. Корольова \\ Носова Г. Д. \\ старший науковий співробітник науково-дослідного відділу \\ інформаційної та кібернетичної безпеки наукового иентру \\ Житомирський військовий інститут імені С. П. Корольова

\section{Наумчак О. М.} \\ ад’юнкт науково-організаційного відділення \\ Житомирський військовий інститут імені С. П. Корольова \\ м. Житомир, Украӥна
}

Всесвітня пандемія COVID-19 суттєво вплинула на загальний підхід до розгортання вступної кампанії усіх закладів вищої освіти (ЗВО) 
України загалом та військових вищих навчальних закладів (ВВНЗ) зокрема. I якщо цивільні ЗВО вже давно широко використовують усі сучасні можливості засобів масової комунікації (ЗМК) мережі Інтернет включно із соціальними мережами (СМ) [1, с. 167], то для ЗВО сектора безпеки й оборони такий підхід є досить новим. Обмеження, пов'язані зі специфікою доступності та відкритості інформації щодо діяльності військових організацій нашої країни, демографічною ситуацією станом на 2020 рік [2], соціальними, політичними та економічними процесами в державі, всесвітньою пандемією COVID-19, $з$ одного боку, та потребами Збройних Сил України щодо укомплектування кваліфікованими офіцерськими кадрами - 3 іншого, виявили певну суперечність під час формування стратегії вступної кампанії 2020 року в Житомирському військовому інституті імені С. П. Корольова.

Компромісом для вирішення цієї суперечності стало максимальне залучення можливостей ЗМК мережі Інтернет із СМ включно для інформування цільових аудиторій (ЦА) щодо вступу до зазначеного ВВН3 - проведення рекламної кампанії навчального закладу.

3 огляду на викладене вище, підготовчим етапом формування стратегії агітації в рамках вступної кампанії 2020 у військовому інституті стало визначення іiї головної мети та ЦА, проведення аналізу нових принципів сприйняття візуальної медіапродукції: техногенності, комунікативності, психологічності [3, с. 59], - значущості візуального медіасприймання, а саме, здатності конкретної ЦА побачити в медіапродукції більше, ніж зображено [3, с. 83], та основних особливостей медіапсихологічного портрета ЦА [3, с. 192]. Наступним кроком стало визначення основних організаційних процесів кампанії [4, с. 103]: від іiі головної мети до факторів [4, с. 282], що впливають на якість організації цих процесів і успішність усіх заходів у цілому, а також показників їх ефективності.

На другому етапі формування стратегії окреслено основні лінії переконання та перелік каналів комунікації [4, с. 290], сформовано необхідний інформаційний простір відповідно до ступеня доступності, зацікавленості та психологічних особливостей сприйняття інформації ЦА.

Усі канали комунікації було класифіковано за типами (рис. 1). При цьому умовний розподіл на «традиційні» й «нетрадиційні» канали застосовано відносно технічних можливостей та історичних передумов, які склалися у ВВНЗ, що розглядається. 


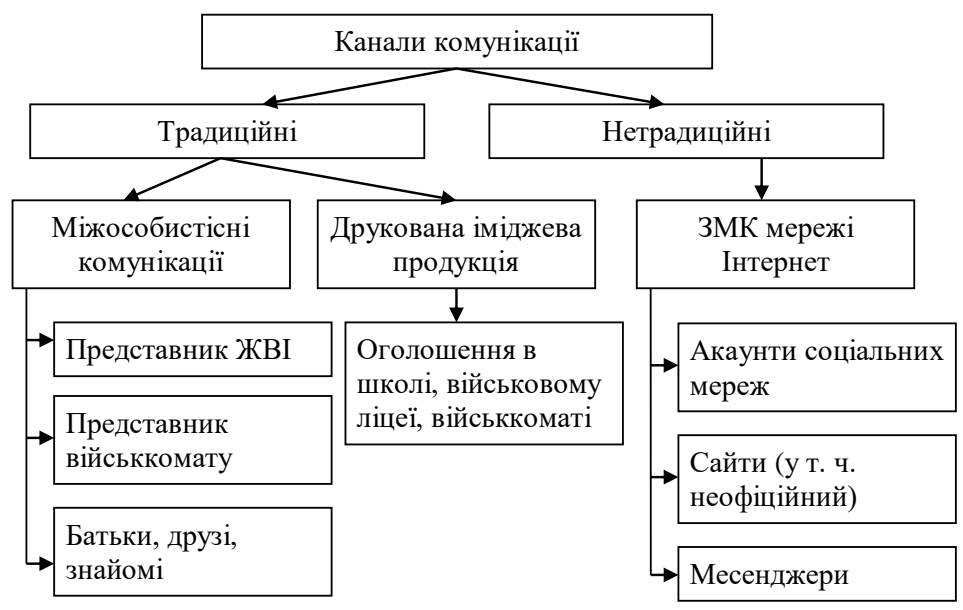

Рис. 1. Класифікація використаних

у рекламній кампанії каналів комунікації за типами

Початком рекламної кампанії можна вважати вересень 2019 року, при цьому нетрадиційні канали комунікації було залучено лише від лютого 2020 року, що відображено діаграмою на рисунку 2.

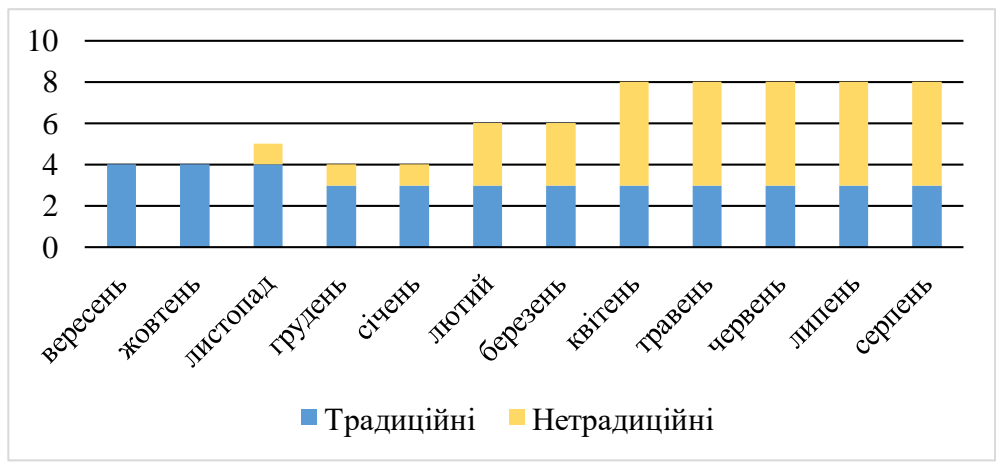

Рис. 2. Активація каналів комунікації протягом вступної кампанії

Інтегральним показником ефективності проведеної вступної кампанії загалом визначено підвищення конкурсу серед вступників до ВВН3. Показник ефективності рекламної кампанії грунтується на 216 
оцінці результативності зусиль, спрямованих на досягнення поведінки ЦА, яка відповідає головній меті та передбачає виконання завдань 3:

- визначення показників (індикаторів) її зміни;

- визначення показників, що свідчать про якість розроблених інформаційних матеріалів;

- визначення показників розповсюдження інформаційних матеріалів;

- спостереження за зміною поведінки ЦА (показники впливу).

Дослідження показників впливу було здійснено шляхом проведення анкетування серед абітурієнтів, яких за результатами відбору було зараховано на навчання до військового інституту. Фрагмент анкети подано на рисунку 3.

\begin{tabular}{|c|c|c|c|c|c|}
\hline \multicolumn{6}{|c|}{$\begin{array}{l}\text { 11. Як вплинула інформація з наведених джерел на Ваше рішення про вступ до Житомирського військового } \\
\text { інституту? (оберіть варіант для кожного джерела та обведіть) }\end{array}$} \\
\hline Джерело & Вплинула & Майже так & Частково & Майже ні & Не вплинула \\
\hline представник інституту & 4 & 3 & 2 & 1 & 0 \\
\hline представник військкомату & 4 & 3 & 2 & 1 & 0 \\
\hline $\begin{array}{l}\text { оголошення в школі (ліцеї, } \\
\text { військкоматі) }\end{array}$ & 4 & 3 & 2 & 1 & 0 \\
\hline батьки, друзі, знайомі & 4 & 3 & 2 & 1 & 0 \\
\hline Facebook & 4 & 3 & 2 & 1 & 0 \\
\hline Instagram & 4 & 3 & 2 & 1 & 0 \\
\hline TikTok & 4 & 3 & 2 & 1 & 0 \\
\hline https://zvir.zt.ua/ & 4 & 3 & 2 & 1 & 0 \\
\hline vstup.do.zvi.tilda.ws/2 & 4 & 3 & 2 & 1 & 0 \\
\hline канал у Telegram & 4 & 3 & 2 & 1 & 0 \\
\hline інше (назвіть) & 4 & 3 & 2 & 1 & 0 \\
\hline
\end{tabular}

\section{Рис. 3. Фрагмент анкети курсантів першого курсу набору 2020 року}

Результати розрахунків проведеного опитування на основі аналізу 283 анкет щодо ступеня впливу інформації, отриманої традиційними та нетрадиційними каналами комунікації, узагальнено в діаграмі, наведеній на рисунку 4.

Результати проведеного опитування з урахуванням початкових умов, за яких було розгорнуто вступну кампанію 2020 у ВВНЗ, що досліджується, підтверджують ефективність застосування нетрадиційних каналів комунікації для проведення агітації ЗВО для визначеної ЦА. Активне використання психологічних та соціальних властивостей медіаресурсів у формуванні іміджу ВВНЗ шляхом проведення рекламної кампанії в ЗМК мережі Інтернет дозволяє ефективно впливати на ЦА для досягнення головної мети. 


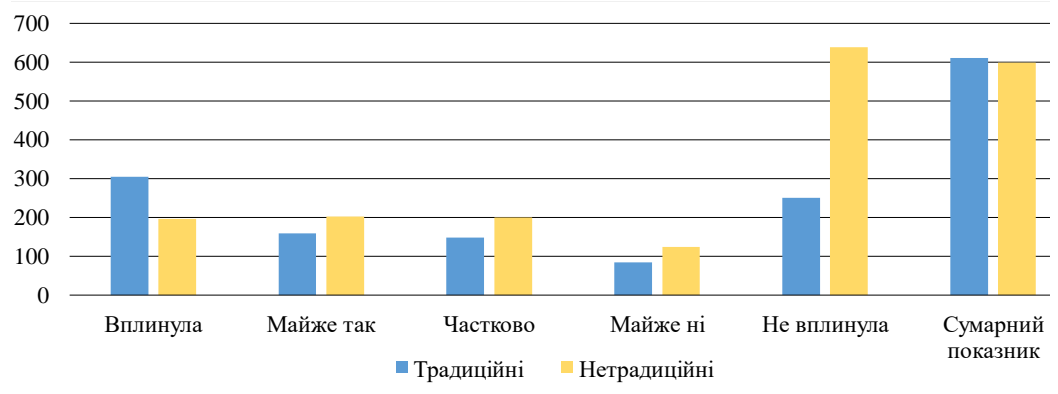

Рис. 4. Аналіз ступеня впливу інформації залежно від типу каналу комунікації

\section{Література:}

1. Шишко В. И., Шишко А. Ю. Алгоритм организации рекламных кампаний в учреждениях высшего образования. Економіка та управління підприємствами: Журнал, 2016. Вип. 10. С. 167-171.

2. Банк даних Державної служби статистики України (Databank of State Statistics Service of Ukraine). URL: http://database.ukrcensus.gov.ua/MULT/Dialog/Saveshow.asp (дата звернення: 17.09.2020).

3. Медіапсихологія: на перетині інформаційного та освітнього просторів: монографія / О. Т. Баришполець, О. Л. Вознесенська, О. Є. Голубєва, Г. В. Мироненко та ін.; за наук. ред. Л. А. Найдьонової, Н. І. Череповської. Київ: Нац. академія пед. наук України, Ін-т соціальної та політ. Психології, 2014. 348 с.

4. Паблик релейшн. Теория и практика: учеб. пособ. / Катлип Скотт, Сентер Аллен, Брум Глен. 8-е изд.; пер. с анг. Москва : Изд. дом «Вильямс», 2003. 624 с. 